\title{
Concerning the Foundation of the Tokyo Botanical Society
}

By

\section{Kingo Miyabe}

Just fifty years ago, on Feb. 25, 1882, the first meeting of the Tokyo Botanical Society was held in the Koishikawa Botanic Garden, belonging to the Tokyo University. It was an auspicious occasion for the Society, which has since developed to a powerful association of about 500 members on its roll, although the number of the members assembled in that meeting did not count more than a dozen. Prof. R. YATABE was elected for its first president. He delivered his inaugural address on the subject, "On the Filices".

The circumstances, that led the young botanists of the time to the foundation of a new Botanical Society, were to separate themselves from the Tokyo Biological Society and to form an independent body of their own. The Tokyo Biological Society was started by Prof. E. S. MoRse in 1878, with Prof. YATABE for its first president, and was intended to include among its members both zoological and botanical students.

The Botanical Section of the Biological Department of the Tokyo University was at its infancy at the time of the birth of our Society. The writer was then the only and first student of botany under Prof. $Y_{\text {ATABE, and }} \mathrm{Mr}$. K. S S SIDA, the first regular student, was admitted to the Department in the autumn of that year. The rest of the students of the Department specialized themselves in zoological studies. $\mathrm{Mr}$. Jinzo Matsumura was then still an assistant of the laboratory and was busily engaged in taxonomic works and in laying the foundation of the Herbarium. Mr. SABUro Oкubo was also an assistant, helping Prof.

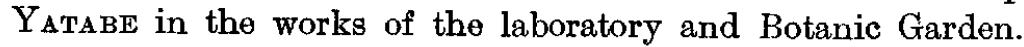

Prof. Yatabe at the time of his return from America in 1876 was a young man of twenty-five years old. In America, after the graduation of the academic course in Cornell University, he attended the summer school of botany of Harvard University, and there he came under the personal influence of Drs. AsA GraY and W. G. FArLOW, who took a special interest on a young aspiring botanist from Japan. Dr. FARLOW took him to Wood's Hole, where he was initiated in the study of marine algæ. Dr. GRAY handed to him at his departure a set of the 
named specimens of the Hokkaido plants, some 400 in number, collected by Lours Boenmer under the direction of Col. Horace CAPron, Commissioner and Adviser of the Kaitakushi (the Hokkaido Colonization Government), in 1874. The specimens had apparently been sent to Dr. GraY by the Kaitakushi through the hand of Col. CAPron for identification and to be returned; but no official records nor correspondence to Dr. Gray concerning the matter could now be found. They were carefully worked over by Dr. Kersuke ITo, who annotated to each specimen the Japanese and Chinese names, if there be any, often accompanied by a scholarly remark.

These specimens formed the foundation of the Herbarium of the Tokyo Imperial University and were of great value and help to Prof. YATABE and his assistants in the study of our plants in those early days of the Botanical Laboratory.

It was at the beginning of the year 1882, that the assistants MATsUMura and Orubo, together with $\mathrm{K}$. Sa wada, H. $\mathrm{K}_{\mathrm{AKU}}$ and T. UchiYama of the Botanic Garden, N. OKADA and K. ONUMA, both amateur botanists and the writer assembled at Mr. OKuBo's house to discuss on the question of the establishment of the new Botanical Society. The young botanists thus gathered together were all full of spirits and enthusiasm. The result of the resolution passed was the opening of the first meeting of the Society in February of the same year, as was stated at the beginning of this paper.

During five years from the time of the birth of the Society to that of the publication of its organ, the Tokyo Botanical Magazine, in 1887, the Society had led a rather inactive and at times precarious existence. But the gradual increase of the new members had revived its activity, which was manifested in the bold attempt of the publication of the monthly magazine. Among the members, who took active part in this enterprise, the names of Saburo Okvbo, Tomitaro Makino, Enjiro Tanaka, Tokugoro Someya, Kotaro Saida, Kotaro Shirai, Manabu Miyoshi, Chikaye Tsuge and Komajiro Sawada should long be remembered. 